\title{
Human Resource Diversity Management in Selected Czech Agricultural Companies
}

\author{
H. Urbancová ${ }^{1}$ H. Čermáková ${ }^{2}, M$. Navrátilová ${ }^{2}$ \\ ${ }^{1}$ Department of Management, Faculty of Economics and Management, Czech University of Life Sciences \\ Prague, Czech Republic \\ ${ }^{2}$ Department of Trade and Accounting, Faculty of Economics and Management, Czech University of Life \\ Sciences Prague, Czech Republic
}

\begin{abstract}
Anotace
Cílem článku je zhodnocení diversity managementu v zemědělských podnicích v rámci České republiky a zpracovat soubor doporučujících opatření pro zkoumané zemědělské podniky v této oblasti. Zpracovávaná primární data byla získána $\mathrm{v}$ rámci kvantitativního výzkumu prostřednictvím dotazníkového šetření $\left(\mathrm{n}=549, \mathrm{n}_{\text {agriculture }}=108\right)$. Výsledky naznačují, že v rámci českých zemědělských podniků je využívání diversity managementu na relativně nízké úrovni $\left(36,1 \% ; n_{\mathrm{a}}=108\right)$. Lze však usuzovat, že se aplikace diversity managementu v rámci agrárního sektoru, vzhledem $\mathrm{k}$ jeho specifické situaci v oblasti zaměstnanosti a zvláštnostem pracovní síly v zemědělství na trhu práce, stane v budoucnosti jednou z důležitých oblastí ř́zení zemědělského podniku.

Tento článek vznikl za podpory celouniverzitního grantu ČZU - CIGA, číslo 20141002 - Budování značky zaměstnavatele pomocí nových strategických trendů v organizacích v České republice.
\end{abstract}

\section{Klíčová slova}

Lidské zdroje, diversity management, zemědělství, Česká republika, pracovní síla, podnik.

\begin{abstract}
The aim of this paper is to evaluate human resource Diversity Management in agricultural companies in the Czech Republic and to prepare a set of recommendations for the companies in this area. The primary data for the study was obtained by the use of questionnaires designed for quantitative analysis $\left(\mathrm{n}=549, \mathrm{n}_{\text {agriculture }}=108\right)$. The results indicate that the use of Diversity Management on Czech companies is relatively low $\left(36.1 \% ; \mathrm{n}_{\mathrm{a}}=108\right)$. But in view of the employment situation in the agricultural sector, as well as the characteristics of the workforce engaged in agriculture, it would appear that Diversity Management will become an important feature of company management in the not so distant future.
\end{abstract}

This contribution is a follow-up to the project of University - wide internal grant agency (CIGA), number 20141002 - Human resource branding using of the new strategic trends in organizations in the Czech Republic.

\section{Key words}

Human resources, Diversity Management, agriculture, the Czech Republic, labour fource, company.

\section{Introduction}

The current state of the world economy exhibits a high degree of globalization. We can see this in the continuously expanding internationalization of corporations', and other business companies', operations, as well as ever growing numbers of foreign born employees on companies' payrolls. At the same time, economic and social differences are deepening both within individual states, and among the states themselves. The demographic changes that have taken place over the past twenty years are having an impact on the economically developed countries. These states are experiencing low and decreasing birth rates (Gendron, 2011; Žnidaršič, Dimovski, 2009). At the same time, the lifespan in developed countries is increasing due to improved health care and progress in the development of medical treatment methods. The amount of time which young people spend 
studying has also increased, which leads them to postpone the start of their working lives. Taken together, this could result in a shortage of qualified workers, as well as causing a crisis in retirement systems (Fiala, 2012). Such longterm adverse effects may be partially ameliorated by the application of new management concepts within companies. One of these is Diversity Management, which has been established as one of the more important trends of the twenty-first century. Managers in both public and private companies are searching for new ways to more effectively lead their employees. To this end they are experimenting with various management approaches in order to find the one that will permit them to react with greater efficiency to the growing diversity of today's workforce (Ivancevich, Gilbert, 2000).

The Diversity Management concept emphasizes the taking of employees' individual personal characteristics into account by company managers. These characteristics include the employees' gender, race, family status and age (Kramar, 2012). Each individual's level of competence, regardless of his/her personal characteristics, contribute to the success of the company. Cummings (2004) says that in structurally diverse work teams; i.e., those in which every individual may contribute his or her unique knowledge for the benefit of the whole; there is an increase in the amount of shared knowledge, thereby creating a synergy effect. An effective exchange of information and knowledge thus brings about greater efficiency, both within the company and in its surroundings.

In a broader context, Diversity Management may also focus on taking other personal characteristics into account, such as sexual orientation, physical and mental abilities; as well as differences within company work groups (Kramar, 2012). Applying Diversity Management within a company brings many positive results. In particular it brings increased prestige and social status, both in the eyes of the public and potential employees. This means ever greater chances for companies to attract and retain the new talent that comes with high quality human resources (Kearney, 2013; International Society for Diversity Management, 2007). According to Choi and Rainey (2010), Diversity Management may have an impact on the overall performance of a company, thus bringing the company a competitive advantage. Diversity Management also becomes a tool for improving employee motivation and creativity. This, in turn, contributes to the creation of innovative processes within the company (Kearney, 2013; International Society for Diversity Management, 2007).

Currently, Diversity Management is an integral part of HR management strategy in companies in all economic sectors. The agricultural sector is characterized by the specific long-term lowering of interest by potential candidates in open positions. This is also supported by data supplied by the Czech Statistics Office (CSO) in 2014, concerning employment statistics in the primary sector, specifically in the agricultural sector.

This paper evaluates human resource Diversity Management in agricultural companies in the Czech Republic and to prepare a set of recommendations for these agricultural companies in this area. The first part of the article presents theoretical background together with comparisons of secondary resources. The chapter Results and Discussion includes an analysis and synthesis of the survey targeted at Diversity Management in agrarian sector in the Czech Republic. A comparison of results with results of similar surveys conducted abroad and draft recommendations are also included in this chapter.

\section{Theoretical background of the work}

Falling employment has been characteristic for the agricultural sector since 1989. The yearon-year reduction of employees in agricultural concerns has also continued into 2013, when it stood at $1.8 \%$. Agricultural employees represented $2.1 \%$ of the total workforce of the Czech Republic; a value identical to that of 2012 (Agricultural Chamber of the Czech Republic, 2014). The total number of people employed in agriculture, forestry and fisheries amounted to 149,600 persons in 2013; of which 105,300 were men and 44,300 were women, under the CZ NACE classification (CSO, 2013).

In 2009 the National Observatory of Employment and Training of the National Training Fund stated that in the coming years the percentage of people employed in the Czech agricultural sector would be comparable to that of the developed Western countries, accounting for $2.45 \%$ of the working population. So, from the point of view of future long term employment prospects, agriculture may be considered an area with relatively low employment opportunity potential. It is forecast that total employment in the agricultural sector will drop by approximately one quarter by 2020 , compared to 2008 (CSO, 2014; National Observatory 
of Employment and Training of the National Training Fund, 2009). In spite of this unfavourable outlook, and the minor role played by agriculture in the total performance of the national economy, this interesting sector is very important. Agriculture is a bearer of a number of functions not related to production, and agricultural facilities play an essential role in the development of rural areas.

Spěšná et al. (2009) state that, in spite of the anticipated future decrease in employment, the introduction of innovative management processes and trends would lead to increased demand for employees who have completed their secondary and tertiary education. According to the National Observatory of Employment and Training of the National Training Fund, current trends in agriculture show that it may be expected that employers will increase their requirements for higher, as well as a broader spectrum of, qualifications, particularly in the areas of biofuels, organic farming, as well as agro tourism.

In the study, Spěšná et al. (2009) state that over the long term, the situation in agriculture - focusing on diversity, and particularly employment - has been much less favourable to women. While the level of male unemployment has not significantly differed over the long term from the indicator value for the entire national sector; the level of unemployment of women in the agrarian sector was high in the period 2001-2008, and several times the level approached double the number of women unemployed within the entire national economy. The proportion of women in agriculture has oscillated around $30 \%$ over the long term (Agricultural Chamber of the Czech Republic, 2014; Agro-census, 2010). This is lower than the average proportion of women in employment in the entire national economy of the CR (43.5\% in the $4^{\text {th }}$ quarter 2013$)$. It is also lower than the proportion of women employed in agriculture in EU (37.4\% in EU27 in 2011). There has also been a reduction in the number of positions for women in the Czech agricultural sector, particularly in relation to the reduced scope of the manufacture of agricultural products; the traditional framework in which they (women) found employment (Agricultural Chamber of the Czech Republic, 2014).

The increasing age of the farming population is an issue not only in the CR, but also in most other European countries. In the 4th quarter of 2013, the greatest number of employees in the sector was, as usual, in the 45-59 age group (44.2\%), followed by those in the 33-44 age group (33.8\%). A smaller proportion was accounted for by employees in the youngest category; the 15-29 age group (11.7\%), with the oldest employees (60+ age group) accounting for $10.3 \%$ of the farming population (Agricultural Chamber of the Czech Republic, 2014).

Year-on-year, the proportion of workers in the 15-29 age group increased slightly (by $1.2 \%$ ), as it also did in the $30-44$ age group (by $0.8 \%$ ), and in the $60+$ category (by $0.5 \%$ ), while the proportion of workers in the 45-59 age group decreased (by 2.5\%). Overall, the proportion of workers in the $45+$ age group was $54.5 \%$ in the agricultural sector; whereas it came to $41.3 \%$ in the wider national economy, while this age group accounted for $40.2 \%$ of workers in the industrial sector, including construction. Although the proportion of employees in the $45+$ age group has decreased by $2 \%$ year-onyear, the age structure of employees in the sector remains significantly more restricted than in the national economy, or in the manufacturing sector (Agricultural Chamber of the Czech Republic, 2014). Changing the age structure of agrarian employees thus is one of the most pressing tasks for the sector. In the 4 th quarter of 2013, the proportion of women in the structure of employment in the agrarian sector amounted to $29.1 \%$ and increased by $1.6 \%$ year-on-year. In agriculture (including game management and related activities), this proportion amounted to $31.2 \%$ and increased by $0.6 \%$ (Agrarian Chamber of the Czech Republic, 2014). So, changing the age structure of agricultural employees is one of the most pressing tasks for that sector. In the 4th quarter of 2013, the proportion of women employed in the agricultural sector amounted to $29.1 \%$, and has increased by $1.6 \%$, year-onyear. In agriculture (including game management and related activities), this proportion amounted to $31.2 \%$, and it has increased by $0.6 \%$ (Agrarian Chamber of the Czech Republic, 2014).

Since 2000, the proportion of foreigners employed in the agricultural sector has not changed significantly, even though the total number of employees of non-Czech origin has declined in the sector (Ministerstvo zemědělství, 2014). Overall, the number of foreigners employed in farming remains insignificant. In 2013, it accounted for only $2.2 \%$ of workers in the sector (CSO, 2013).

Based upon the facts above, the statistical correlation between the application of Diversity Management 
in selected companies and the qualitative features identified in the theoretical basis were explored.

\section{Materials and methods}

Our data was mainly extracted from secondary sources, and our analysis and discussion are linked to the outcome synthesis, as well as the evaluation of the research results. The primary data used in the study was obtained as part of a quantitative research project, which was carried out using a questionnaire survey. The companies were selected on a random basis and the sample included $n=549$ companies in all sectors as classified by CZ-NACE of which $\mathrm{n}_{\text {agriculture }}=108$ were agricultural companies (primary sector). Randomly selected companies were contacted by e-mail. The questionnaire consisted of four parts that include 48 questions in total. Only the second part of questionnaire was on human resource Diversity management and the last part was focused on Classification questions. Most of the questions were closed questions.

In each company a single respondent was addressed. Questionnaires were filled out on behalf of individual companies by employees in managerial positions (with at least one direct subordinate), by a HR manager. Others who could fill the questionnaire were: the person responsible for HR management in the company, or a line manager. Company owners and middle or top-level managers also performed this task.

As of $30^{\text {th }}$ June, 2014, a total of 108 companies had taken part in the research. Their structure is as follows:

- Classified by size, based upon the number of employees, this group of businesses included 73 small companies (68.2\%) with up to 50 employees; along with 28 medium sized companies (26.2\%) with 51 to 249 employees. 6 large agricultural concerns with 250 or more employees accounted for $5.6 \%$ of the total number of entities included in the survey.

- In terms of the share of ownership, the overwhelming majority of companies in the research was Czech $(95.3 \%$, i.e., 102 enterprises). Only 5 of them (4.7\%) had a foreign majority shareholder, or shareholders. Most of the companies are located in the Central-Bohemia (44.4\%); Prague (14.8\%) and Ústí nad Labem regions $(8.3 \%)$. The average for other regions was $2 \%$.
- In $64.8 \%$ of the companies, more men are employed than women. Only in $15.7 \%$ of the companies did women prevail over men; while in $19.4 \%$ of the agricultural companies the proportion of women and men is equal. In $80.4 \%$ of the agricultural companies, more than $6 \%$ of the employees are older than 55 . Only in $1.9 \%$ of them was the number of foreigners employed there greater than the number of Czechs.

The data were evaluated using the tools of descriptive statistics and the methods of comparison, induction, deduction, and synthesis. Descriptive statistics used to test $\mathrm{t}$ he results included absolute and relative frequency, correlation analysis, and a non-parametric Pearson Chi-square test. 2 null hypotheses were tested:

- $\mathrm{H}_{0} 1$ : The use of human resource Diversity Management does not depend on the sector.

- $\mathrm{H}_{0} 2$ : The use of human resource Diversity Management does not on sector size.

If the $\mathrm{p}$-value calculated by means of the $\chi^{2}$ test (Pearson Chi-Square) was lower than the selected level of significance $\alpha=0.05$, null hypothesis was rejected (Hendl, 2012). The analysis was carried out using the IBM SPSS Statistic Desktop 22.

\section{Results and discussion}

This section contains the evaluation of the data, their interpretation, and recommendations. It focuses on the assessment of the current situation as regards the Diversity Management in Czech agricultural companies. The "Results" section is followed by the discussion and conclusions, which summarize the recommendations indicated by the results.

Because of the specific focus of Diversity Management on companies in agrarian sector, the relationship between the use of Diversity Management and the economy in general $(n=549)$ was determined. Statistics show that the p-value equals 0.006 , and for this reason the null hypothesis may be rejected, and the alternative hypothesis that the feature exists may be accepted. The use of Diversity Management thus depends upon the sector (H01). The dependency strength (Cramer's V) is 0.136 (weak dependency). Therefore, Diversity Management is mostly used by companies in the tertiary sector, and it is used the least by those in the primary sector. This is because most agricultural enterprises are family businesses, traditional in nature, and, so, the employment of foreigners under conditions of Diversity 
Management would not be pertinent.

The connection between the size of the company and the use of Diversity Management in Czech companies was also determined. The p-value is equal to 0.000 , and the null hypothesis may thus be rejected and the alternative hypothesis accepted. The use of Diversity Management, therefore, depends upon sector size (H02). Dependency strength (Cramer's V) is 0.210 (weak dependency).

Evaluation of Diversity Management in Czech agricultural companies

The results show that only $36.1 \%$ of the agricultural companies addressed currently makes use of Diversity Management. Most agricultural companies have not paid much attention to the concept of Diversity Management, mainly because they have inadequate information. Only $15.7 \%$ of the agricultural companies addressed indicated that they, in fact, knew something about the concept of Diversity Management. Meanwhile, according to the Czech Statistics Office (2014), the lack of jobs in agriculture, and the employee structure by age and gender, clearly show the presence of employment issues on Czech agricultural companies. Table 1 shows the absolute frequency of agricultural companies' (according to size) use of Diversity Management.

Of the large agricultural companies, which participated in the research, 50\% use Diversity Management in their personnel management practices. For medium size agricultural companies the figure is $42.9 \%$, while only $32.4 \%$ of small agricultural companies use Diversity
Management. These results show that the smaller the agricultural company, the less it focuses on Diversity Management. Agricultural companies are mostly only small family businesses (with up to 20 employees). For this reason, it may be deduced that they do not make much use of the Diversity Management strategy due to their having insufficient information at their disposal, as well as the existence of misconceptions about Diversity Management (e.g., that it is costly), in addition to its being time consuming. Table 2 summarizes the final number of agricultural company employees by gender.

Of the $29.4 \%$ of Czech agricultural companies that do use Diversity Management, women employees outnumber the men. $38.1 \%$ of Czech agricultural companies have an equal, or nearly so, number of women and men employees; while in $37 \%$ of agricultural companies, there are more men employees than women. Overall, within the set of agricultural companies selected for the survey, $15.7 \%$ of them employ more women. This slightly contradicts the data provided by Agro-census (2010), which indicates that the number of women employed in agriculture has been oscillating around $30 \%$ over the long term. This slight discrepancy may be due not only to the different time periods during which these independent studies were carried out, but also to the manner in which the agricultural companies were selected from the database maintained by the Agricultural Chamber of the Czech Republic. Statistics show that the correlation between the use of Diversity Management in selected

\begin{tabular}{|l|c|c|c|c|}
\hline & \multicolumn{3}{|c|}{ Company size by the number of employees } & \multirow{2}{*}{ Total } \\
\cline { 2 - 4 } & Up to 50 employees & $\mathbf{5 1 - 2 4 9}$ employees & $\mathbf{2 5 0}+$ employees & \\
\hline Yes & $24(32.4 \%)$ & $12(42.9 \%)$ & $3(50 \%)$ & $39(36.1 \%)$ \\
\hline No & $50(67.6 \%)$ & $16(57.1)$ & $3(50 \%)$ & $69(63.9 \%)$ \\
\hline Total & $\mathbf{7 4}$ & $\mathbf{2 8}$ & $\mathbf{6}$ & $\mathbf{1 0 8}$ \\
\hline
\end{tabular}

Source: own survey

Table 1: Application of Diversity Management in agricultural companies by number of employees.

\begin{tabular}{|l|c|c|c|c|}
\hline & \multicolumn{3}{|c|}{ The proportion of men and women in agriculture } & \multirow{2}{*}{ Total } \\
\cline { 2 - 4 } & $\begin{array}{c}\text { More women than } \\
\text { men }\end{array}$ & $\mathbf{5 0 \% : 5 0 \%}$ & $\begin{array}{c}\text { More men than } \\
\text { women }\end{array}$ & \\
\hline Yes & $5(29.4 \%)$ & $8(38.1 \%)$ & $26(37.1 \%)$ & $39(36.1 \%)$ \\
\hline No & $12(70.6 \%)$ & $13(61.9 \%)$ & $44(62.9 \%)$ & $69(63.9 \%)$ \\
\hline Total & $\mathbf{1 7}$ & $\mathbf{2 1}$ & $\mathbf{7 0}$ & $\mathbf{1 0 8}$ \\
\hline
\end{tabular}

Source: own survey

Table 2: Use of Diversity Management on Czech agricultural companies by employee gender. 
agricultural companies and the proportion of men and women employed was not statistically significant ( $p$-value $=0.819$ ). The use of Diversity Management according to the number of foreign born employees is depicted in Table 3.

The results clearly show that most workers $(96.3 \%)$ on Czech agricultural companies are Czech. This is something which has also been confirmed by studies carried out by the Trade Union of Food and Agriculture Workers (2014) showing that foreigners account for only $2.2 \%$ of employees in the agricultural sector (CSO, 2013).

Another no less important aspect of Diversity Management in the agricultural sector is the employee structure. Table 4 provides a detailed breakdown of the employee composition on the agricultural companies which were studied.

The results show that people working in agriculture are mostly members of the older age group. 59.3\% of the participating agricultural companies have more than $51 \%$ of their employees in the $55+$ age group. These results support the statements of the Agricultural Chamber of the Czech Republic (2014) that the aging agricultural population is an issue which confronts not just the CR, but most other European countries. The research results agree with the official figures given by the Agricultural
Chamber of the Czech Republic (2014), which state that the overall proportion of workers in the $45+$ age group stands at $54.5 \%$ in the agricultural sector.

These facts show that the areas covered by Diversity Management (employee age, gender, number of foreign born employees, etc.) must be addressed, not only by the tertiary sector, where the situation is relatively positive, but it must also be dealt with by the primary sector, where the long-term prospects for the employment situation are problematic. This was confirmed by Spěšná et al. (2009), as well as by Urbancová and Hlavsa (2014).

\section{Discussion}

Total $33.3 \%$ of the participating agricultural companies have stated that Diversity Management gives them a competitive advantage. These were mainly small agricultural companies (80.6\%). $69.4 \%$ of them employ mostly men.

Globalisation has an impact on all current economic processes. It is also reflected in the demographic changes, and for this reason, diversity should be taken into account in business companies in every sector of the economy. Diversity includes variety in the composition of the labour force, as well as

\begin{tabular}{|l|c|c|c|c|}
\hline \multirow{2}{*}{} & \multicolumn{3}{|c|}{ Proportion of foreigners employed vs. Czechs } & \multirow{2}{*}{ Total } \\
\cline { 2 - 4 } & More Czechs & $\mathbf{5 0 \%} \mathbf{5 0 \%}$ & More foreigners & \\
\hline Yes & $36(34.6 \%)$ & $2(100 \%)$ & $1(50 \%)$ & $39(63.9 \%)$ \\
\hline No & $68(65.4 \%)$ & $0(0 \%)$ & $1(50 \%)$ & $69(63.9 \%)$ \\
\hline Total & $\mathbf{1 0 4}$ & $\mathbf{2}$ & $\mathbf{2}$ & $\mathbf{1 0 8}$ \\
\hline
\end{tabular}

Source: own survey

Table 3: The use of Diversity Management in agricultural concerns according to the number of foreign born employees.

\begin{tabular}{|l|c|c|c|}
\hline \multirow{2}{*}{$\begin{array}{l}\text { Number of employees } \\
\text { in category 55+ }\end{array}$} & \multicolumn{2}{|c|}{ Diversity Management implemented } & Total \\
\cline { 2 - 4 } & Yes & No & \\
\hline $0-5 \%$ & 4 & 9 & 21 \\
\hline $6-10 \%$ & 7 & 11 & 16 \\
\hline $11-15 \%$ & 5 & 9 & 16 \\
\hline $16-20 \%$ & 7 & 10 & 16 \\
\hline $21-30 \%$ & 6 & 5 & 9 \\
\hline $31-40 \%$ & 4 & 2 & 7 \\
\hline $41-50 \%$ & 5 & 6 & 7 \\
\hline $51 \%$ and more & 1 & $\mathbf{6 9}$ & $\mathbf{1 0 8}$ \\
\hline Total & $\mathbf{3 9}$ & & \\
\hline
\end{tabular}

Source: own survey

Table 4: Use of Diversity Management in agricultural facilities by employee age structure. 
eradicating discrimination (on grounds of age, race, gender, etc.), while emphasizing the various needs of customers and business partners.

Thus, this paper makes the following recommendations to agricultural companies:

- In terms of human resources, it is recommended that the focus be placed directly on work performance, and the workrelated behaviour of employees, and that discrimination on the usual grounds (age, gender, race, etc.) be avoided.

- Concerning education, workshops should include themes related to Diversity Management. Kormanik and Rajan (2010) recommend paying attention primarily to higher level management. This is usually the instigator and bearer of corporate culture. Thus, a gradual implementation of Diversity Management practices in the economic life of every enterprise in all sectors of the economy may be anticipated.

- In terms of communication, emphasis must be placed upon active communication with employees about Diversity Management, taking their opinions into account, and making them active participants in important organizational decisions. This was confirmed in a study by Sabharwal (2014). This will increase employee self-confidence, personal commitment and feelings of loyalty for corporate policy.

The proposed recommendations cover the various areas of company management and their implementation at all levels of management must be taken into account. Introduction of these measures is conditional upon the company's ability to flexibly adapt to change, as well as upon a positive approach by management. Thus, diversity in the workplace may become a competitive advantage which will contribute to building up the employer's brand (Kormanik, Rajan, 2010).

Most enterprises operating in the agricultural sector will consider Diversity Management as being prestigious but, to some extent, also essential, given the specifics of employment in this sector.
The abovementioned facts show that Diversity Management is a suitable, and important tool for HR management on agricultural companies. Therefore, it is advisable to pay attention to it in good time.

\section{Conclusion}

In the current competitive environment, Diversity Management may be considered one of the strategies which HR managers have at their disposal. The research results show that the use of Diversity Management depends upon the sector in which a given business operates ( $p$-value $=0.006$; Cramer's $\mathrm{V}=0.136)$. It also depends upon the size of the particular business ( $\mathrm{p}$-value $=0.000$; Cramer's $\mathrm{V}=0.210$ ). Regarding the agricultural sector, only $36.1 \%$ of the agricultural companies which participated in the research currently make use of Diversity Management. 33.3\% of participating agricultural companies indicated that making use of Diversity Management leads to their acquiring a competitive advantage. They were particularly small businesses $(80.6 \%)$, of which $69.4 \%$ were agricultural companies employing mostly men. It must be noted that appreciating and supporting the human potential of each person in a diverse workforce is an economic and social benefit for every business. It is also something that reinforces the employer's brand.

The theoretical benefit of this paper is the verification and support which it offers for the theoretical requirements for introducing Diversity Management into the agricultural sector. On the practical level, this paper presents results obtained from the 108 agricultural companies which were observed, as well as recommending a set of measures to be taken by agricultural companies which are still only in the planning stages of introducing the Diversity Management concept.

\section{Acknowledgements}

This contribution is a follow-up to the project of University - wide internal grant agency (CIGA), number 20141002 - Human resource branding using of the new strategic trends in organizations in the Czech Republic.

Corresponding author:

Ing. Hana Urbancová, Ph.D.

Department of Management, Faculty of Economics and Management,

Czech University of Life Sciences Prague, Kamýcká 129, 16521 Prague 6, Czech Republic

Phone: +420 22438 2026, E-mail: urbancova@pef.czu.cz 


\section{References}

[1] Agrarian Chamber of the Czech Republic, Souhrn ke zprávě o stavu zemědělství za rok 2013, [Online]. [cit. 2015-01-29]. Available: http://www.apic-ak.cz/data_ak/14/1/pr/ZelZprava2013.pdf [Accessed: 15 Jan. 2014].

[2] Agrocenzus 2010, Počty zemědělců klesají, Czech Statistical Office, August 2011. [Online]. Available: http://www.czso.cz/csu/tz.nsf/i/agrocenzus_2010 [Actualized: 26. 8. 2011] [Acessed: 10 Jan. 2015].

[3] Czech Statistical Office, Klasifikace ekonomických činností (CZ-NACE), [Online]. Available: http://www.czso.cz/csu/klasifik.nsf/i/klasifikace_ekonomickych_cinnosti_(cz_nace) [Actualized: 18.9.2014] [Acessed: 10 Jan. 2015].

[4] Cummings, J. N. Work groups, structural diversity, and knowledge sharing in a global organization. Management science. 2004, Vol. 50, No. 3, p. 352 - 364. ISSN 1526-5501.

[5] D‘Netto, B., Shen, J., Chelliah, J., Manjit, M. Human resource diversity management practices in the Australian manufacturing sector, The International Journal of Human Resource Management. 2015, Vol. 25, No. 9, p. 1243-1266. ISSN 0958-5192.

[6] Fiala, T., Langhamrová, J., Miskolczi, M., Pavlík, Z. Vývoj některých demoekonomických charakteristik zohledňujících zvyšování důchodového věku v ČR. RELIK 2012 Reprodukce lidského kapitálu - vzájemné vazby a souvislosti. Slaný: Melandrium, 2012. ISBN 978-80-86175-82-9.

[7] Gendron, B. Older workers and active ageing in France: the changing early retirement and company approach. The International Journal of Human Resource Management. 2011, Vol. 22, No. 6, p. 1221 - 1231. ISSN 0958-5192.

[8] Hendl, J. Přehled statistických metod: analýza a metaanalýza dat. 4., enlarged ed., Prague: Portál, 2012, ISBN 978-80-262-0200-4.

[9] Choi, S., Rainey, H. G. Managing Diversity in U.S. Federal Agencies: Effects of Diversity and Diversity Management on Employee Perceptions of Organizational Performance. Public Administration Review. 2010, Vol. 70, No. 1, p. 109 - 121. ISSN 0033-3352.

[10] International Society for Diversity Management, Diversity Management: Training Manual, Idm - International Society for Diversity Management, Sep. 2007 [Online]. Available: http://www.idm-diversity.org/files/EU0708-TrainingManual-cs.pdf [Accessed: 21 Jan. 2015].

[11] Ivancevich, J. M., Gilbert, J. A. Diversity Management Time for a New Approach. Public Personnel Management. 2000, Vol. 29, No. 1, p. 75-92. ISSN 0091-0260.

[12] Kramar, R. Diversity management in Australia: a mosaic of concepts, practice and rhetoric. Asia Pacific Journal of Human Resources. 2012, Vol. 50, No. 2, p. 245 - 261. ISSN 1744-7941.

[13] Kearney, E. Diversity und Innovation. Kreativität, Innovation, Entrepreneurship. Germany: Springer Fachmedien Wiesbaden, 2013, p. 193-213. ISBN 978-3-658-02551-9.

[14] Kormanik, M. B., Rajan, H. Ch. Implications for Diversity in the HRD Curriculum Drawn From Current Organizational Practices on Addressing Workforce Diversity in Management Training. Advances in Developing Human Resources. 2010, Vol. 12, No. 3, p. 367-384. ISSN 1552-3055.

[15] National Observatory of Employment and Training of the National Training Fund. Předvídání kvalifikačních potřeb trhu práce. Prague: Linde nakladatelství, s.r.o., 2009. ISBN 978-808-6131-849.

[16] Ministry of Agriculture. Zemědělská výroba [Online]. Available at: http://eagri.cz/public/web/mze/ zemedelstvi/ [Accessed: 5 June 2015].

[17] Sabharwal, M. Is Diversity Management Sufficient? Organizational Inclusion to Further Performance. Public Personnel Management. 2014, vol. 43, No. 2, p. 197-217. ISSN 0091-0260. 
[18] Spěšná, D., Pospěch, D., Delín, M., Nohel, F., Drlík, J. Agrární trh práce: (research study). Prague: Institute of Agricultural Economics and Information, 2009. ISBN 978-808-6671-703.

[19] Urbancová, H., Hlavsa, T. Age Management Principles in Czech Agrarian Sector. AGRIS on-line Papers in Economics and Informatics. Prague: Faculty of Economics and Management, Czech University of Life Sciences Prague, 2014, Vol. 6, No. 3, p. 93-102. ISSN 1804-1930.

[20] Žnidaršič, J., Dimovski, V. Retaining Older Workers: Fields of Action-Constituting A Comprehensive Age Management Model. Journal of Applied Business Research. 2009, Vol. 25, No. 4 , p. 85 - 97. ISSN 2157-8834. 